Vol. 3, No. 2, 2016

UDC 338.439.

Ye. Krykavskyy

Doctor of Economic Sciences, Professor

O. Kostyuk

$\mathrm{PhD}$ in Economics, Associate Professor

Lviv Polytechnic National University

\title{
THE MACRO-LOGISTICS CONCEPT ON THE NATURAL GAS MARKET IN UKRAINE: IMPLEMENTATION ATTEMPT
}

\begin{abstract}
The problem of introducing market relations into the natural gas market in Ukraine is modified. Studies of natural gas market of Ukraine as a macro-logistics complex system based on the implementation of the logistics concept are offered. The necessity of optimization of reserving natural gas in underground gas storages (UGS). The directions of modernizing the system of pricing for services on the natural gas market in Ukraine are explained, through the transformation of conditional permanent costs, primarily costs of creation and maintenance of technological gas reserves into variable costs of the gas market subjects.

Keywords: The macro-logistics concept, natural gas market in Ukraine, underground gas storages (UGS), macro-logistics complex system.
\end{abstract}

\section{Introduction}

The world market for natural gas is rather monopolized by the countries-producers, and for reasons of national security for European countries it regularly updates the issue of diversifying sources of supply. It is also typical for Ukraine, which in addition to large consuming volume is still a monopolist in transition of Russian gas. The long history of relations between Russia and Ukraine on natural gas market is more concerned with political than economic issues. On the one hand, natural gas is a critical resource for Ukraine's national security because of the extremely low substitution on the retail market (in the housing sector), on the other hand, the general effect on its seasonal demand is done by climatic/weather factors that lower the reliability of medium term demand forecast. Both of these reasons cause the accumulation of gas reserves in the summer period to use it if necessary in the winter period when the country's need exceeds the current gas debit.

Nature has provided Ukraine with such a benefit as large capacity underground gas storages (UGS), which use as an intermediate storage of gas requires its purchases from gas suppliers (internal and external), injection into these storages, storage during a particular period and, if necessary, deflation into the transport network for the purposes of consumption. It is important to ensure that gas reserves in underground gas storage facilities provide a dynamic current balance of gas in a structured and time dimension in space, serve as safety stock, cycle, anticipative, speculative, etc. Meanwhile, power of underground gas storage facilities can be provided to outsourcing as a concentrated demand of Western and Central Europe can technically be satisfied from these storages. However, the key issue is what volumes of gas have to be accumulated in the summer (season) and who is supposed to do that?

\section{Analysis of recent studies}

Since the beginning of the independence of Ukraine (1991) natural gas market has experienced a radical change from the absence of any market economy on the gas market (which therefore did not include the gas market), till its real establishment and operation, performing a variety of macro-functional monopoly (political) influence on the state, wild enrichment and corruption of senior civil officers. Only after the Revolution of Dignity, in terms of Russian gas blockade just within 3 years Ukraine managed to "jump off of Russian gas needle" [2; 6], simultaneously reducing the consumption of gas and diversifying the structure of external suppliers.

The dynamics of consumption and structure of imports indicates significant positive changes on the gas market in Ukraine. There are at least three changes:

- diversification of external sources of gas supply (although the problem of transparency and competition in choosing suppliers still exists);

- gradual transition to market prices;

- stable tendency to reduce gas consumption.

It remains important to get the last change: acquiring high profitability by this market. And there is the standard dilemma here: either to increase revenues or to reduce costs. Obviously, their combination is possible. 
Imports of gas to Ukraine (billion cubic meters)

\begin{tabular}{|c|c|c|c|c|c|c|c|}
\hline \multirow{2}{*}{$\begin{array}{l}\text { Country } \\
\text { Years }\end{array}$} & \multirow[b]{2}{*}{ Total } & \multicolumn{4}{|c|}{ Including } & \multicolumn{2}{|c|}{ Note } \\
\hline & & $\begin{array}{c}\text { Russian } \\
\text { Federation }\end{array}$ & $\begin{array}{c}\text { Slovak } \\
\text { republic }\end{array}$ & Hungary & Poland & Own extraction & Consuming \\
\hline 2013 & 28,0 & 25,8 & 0 & 1,2 & 0,9 & 21,4 & 50,4 \\
\hline 2014 & 19,5 & 14,5 & 3,6 & 0,6 & 0,9 & 20,5 & 42,6 \\
\hline 2015 & 16,4 & 6,1 & 9,7 & 0,5 & 0,1 & 19,9 & 33,7 \\
\hline 2016 & 11,1 & 0 & 9,1 & 1 & 1 & 20,2 & 30,3 \\
\hline
\end{tabular}

Source [2; 6]

Following the basic hypothesis that in terms of growth and a good rate of economic development the priority is profit, and the crisis situation should emphasize the expenditures, so we try to justify specific provisions to reduce costs, based on the macro-logistics concept. These studies are caused by annual (seasonal) media attention to spreading fear and panic regarding possible exhaustion of gas from underground gas storage facilities before the end of the heating season because of insufficient amounts of gas reserves in underground storage facilities [1], or its quick use in colder periods [3]. Recently there has appeared an analytical article explaining the enhanced media attention to the issue of gas reserves [17], which stated that 420 news reports were devoted to this issue during the period of 1-17 January 2017. Anxiety is added by uncoordinated assessment of the Government and 'Naftogaz' of Ukraine on the necessary volumes of gas storage in underground gas storage at the beginning of the heating season, which differed by 3 billion cubic meters [3]. Generally there are many pessimistic forecasts about the safety factor of Ukrainian gas transportation system (GTS) [4], though 'Naftogaz' of Ukraine assured good assessment of the situation even under crisis scenarios [4]. Note that this does not undertake expenditure, although crisis management needs to regard them, because the problem of stocks has always two sides: one - the effects of stocks depletion, second - the consequences of keeping stocks.

There is just one example we would like to demonstrate here. Imagine that as a result of the heating season the excess stock amounted 1 billion cubic meters of gas in the UGS. With a purchase price at 200 USD per 1,000 cubic meters it is $200 \mathrm{mln}$ USD of 'frozen' capital. At a rate of return on equity of $10 \%$ a semi-annual maintenance of this reserve means 10 mln USD of spending its 'frozen' amount. We can only add the cost of transport from the supplier, the cost of pumping, storage and selection, and this amount will be doubled, which is half a billion in
UAH. And what if extra gas reserves amounted 2 billion cubic meters? This is equal to a billion UAH of foregone profits. And it is questionable how to evaluate the fact that at the beginning of spring Ukraine has the largest reserves of natural gas among all European countries.

According to the logistics chain/ network concept of gas supply the supplier has traditional phase of supply: supply - distribution consumption, which occurs during transportation, consolidation (association) in the GTS, storage in stock reserves (UGS), deconsolidation (distribution) and consumption. Some processes involve customs barriers, others - engineered barriers (injection, selection). And everywhere there are generated costs, the level of which depends on the physical volumes and unit costs.

So, as any logistic flow, in terms of the economy two parameters of its effectiveness are extremely important for the gas flow:

- The level of gas reserves;

- Turnover (rotation) of gas reserves.

In other words, reducing the average stock in the GTS, we, on the one hand, reduce the cost of its creation, maintenance (pumping, storage, selection), and manipulative move (UGS as virtual entire complex), on the other hand - make its turnover faster, reducing inventory turnover cycle, and thus the cycle of customer service.

The objective of the article is to introduce the directions of the macro-logistics concept into the natural gas market in Ukraine.

\section{Key problem analysis}

Based on logistics paradigms it should be categorically accepted that the natural gas market in Ukraine is an especially difficult macro-logistics system, which main research subjects are:

- physical movement of natural gas (transporting process);

- retention of gas in storage (stock); 
- logistics costs (transportation costs, inventory, administrative and management costs);

- the information flow accompanying the gas flow, another tangent relevant information;

- infrastructure of logistics processes.

Obviously, each of these subjects may have a particular potential to improve efficiency of the natural gas market, in particular the cost, quality, customer service, flexibility, innovation and environmental benefits that also may require either unimportant or significant efforts (capital investment, time, reengineering, change management, etc.). The study of the defined systems should keep to the principles of logistics concept as thinking in categories of value/utility, system thinking categories, the categories of full/total expenditures, categories of efficiency and customer service categories.

Regarding the first set (transport processes), no significant reservations with regard to satisfactory technical conditions of GTS, necessary modernization of equipment, high labor discipline and good state of GTS engineering management. This equally applies to the information flow and infrastructure of logistics processes. Although, there is a significant opportunity to optimize the processes of production and transportation, taking into account the level of technological gas consumption in these processes, which is more than $10 \%$ of consumption (in $2013-4.3$ billion cubic meters in $2014-3.7$ billion cubic meters) [16]. However, there are great restrictions about public policy management (creation, storage replenishment, maintenance and use) of reserves in UGS. Obviously, in the corresponding structures of 'Naftogaz' Ukraine there are documents and standard procedures for making decisions regarding inventory levels for different scenarios, but the fact of the recent reduction of insurance reserves for suppliers from $50 \%$ to $10 \%$ [7] causes doubts about the economic justification for such a decision, and shows that it is rather a political decision, though with positive content.

When evaluating a particular level of gas reserves, we always aim to get answers regarding its adequacy in terms of occurrence of certain deviations of actual demand from projected demand, both expected and unexpected, especially in crisis situations. However, we must also realize that excess inventory and insufficient supplies cause additional costs: with an excess reserves - the additional costs of creating and maintaining, with insufficient stocks - costs of stocks exhaustion (cost of lost sales, lost profits, cost of gas substitution, obvious and not obvious costs of social, political type, associated costs, etc.).

Thus, we have a classic situation of trade off: holding low stocks we get the risk of additional costs and the depletion of stocks, and the opposite: high stocks lead to the additional costs of creating and storing, but less risk of exhaustion. And the "arbitrator" in this situation serves a particular stock level in the system. Graphically this can be represented as follows (Fig. 1).

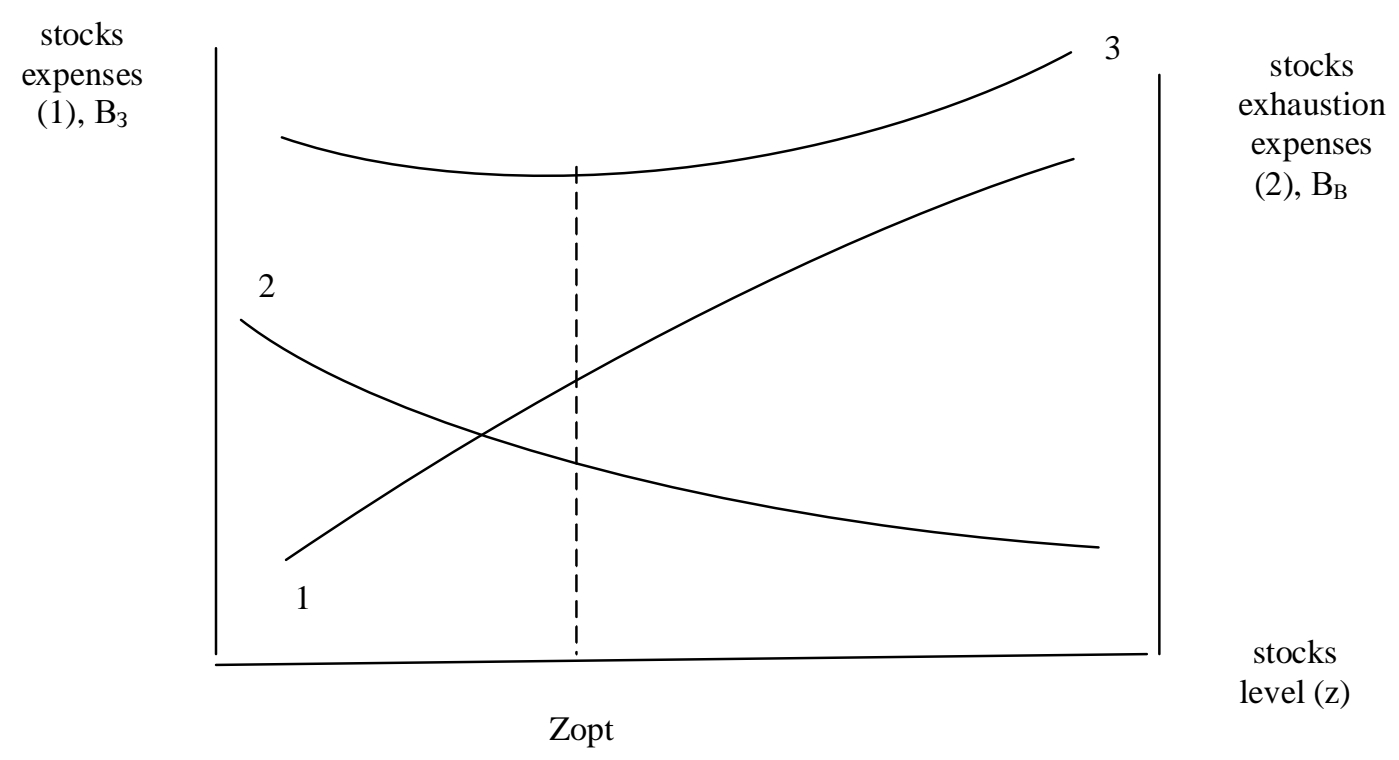

Fig. 1. The ratio of stocks expenditure (1) stocks exhaustion costs (2) and their sum (3) 
Figure 1 shows a hypothetical curve (3) as the sum of stocks costs (costs of creation and storage of stocks) and the likely costs of stocks exhaustion exemplifies the existence of "arbitration" of stocks level (Zopt):

$$
\text { Zopt }=f() \text {, }
$$

its credibility is entirely determined by the reliability of forecasts of deviations, factors, estimates, etc. At the same time, it can be assumed that this level should not necessarily be universal, the same for all supply gas chains on the natural gas market in Ukraine. Obviously, the principle of unification of stock maintenance is good in terms of control, monitoring, provision of similar barriers of entry/exit, but not always economically rational as both suppliers and consumers / customers can vary significantly by conditions and prerequisites for doing business, avoiding crisis situations and others.
Therefore, the authors offer to implement a differentiated approach to setting standards of mandatory reserves, but using the principles of the typical basis of structuring gas reserves by the functions they performed. Usually, the logistics concept transforms the reasons of accumulation of certain stocks to respective functions. Traditionally the following reasons of stocks accumulation are distinguished:

- Savings while purchasing;

- Savings in transportation;

- The need for a guarantee (insurance) stock;

- The need to create seasonal stock;

- The need to create promotional reserve;

- The expediency of creating a speculative stock.

According to these reasons, the total amount of stock can be classified / structured by functions, as shown in [12, p. 247] (Table 2).

\section{Functional classification of everyday consumer goods' stocks}

\begin{tabular}{|c|l|c|}
\hline No. & \multicolumn{1}{|c|}{ Functional purpose } & Type of stock \\
\hline 1 & $\begin{array}{l}\text { Compensating the lack of harmonization (synchronization) of intensity } \\
\text { levels of demand in related supply chain }\end{array}$ & Current (cyclic) \\
\hline 2 & $\begin{array}{l}\text { Meeting the unexpected increase in demand, intensity, and also because } \\
\text { of delays in the implementation of orders and incomplete orders }\end{array}$ & Guarantee (margin of safety) \\
\hline 3 & $\begin{array}{l}\text { The same, but because of the possible strikes, unfavorable political } \\
\text { conditions, deviations from the stationary conditions, etc. }\end{array}$ & Insurance (security) \\
\hline 4 & $\begin{array}{l}\text { Holding stock to meet foreseen demand, particularly its growth, and to } \\
\text { increase the space-time product availability to the customer }\end{array}$ & Leveling \\
\hline 5 & $\begin{array}{l}\text { Leveling the time difference between the amount of the purchase, } \\
\text { transport and mode of production and supply in the chain of distribution, } \\
\text { its variations, including seasonal, which makes it possible to optimize the } \\
\text { use of production capacity in the supply chain }\end{array}$ \\
\hline 6 & $\begin{array}{l}\text { Ensuring timely supply in case of significant distances between the } \\
\text { supplier and the recipient }\end{array}$ \\
\hline 7 & $\begin{array}{l}\text { Loss of functionality and lack of benefits of its ownership in operation } \\
\text { stationary conditions }\end{array}$ & Stock on the way \\
\hline
\end{tabular}

Source: [12, p. 247].

Taking presented in Table 2 functional separation of stocks as a basis, an algorithm of actions for calculating stock levels is proposed:

1. Differentiated identification of the functions of gas reserves. Obviously, for different customers (communal services, manufacturing, and energy sector) the relevance of certain features may vary.

2. Calculation of norms for creation and storage of stocks by their functionality

3. The construction of these standards into a unified norm of gas reserves.
The proposed algorithm of setting norms for stock level will ensure its differentiated use more reasonable to interpret the relationship between the subjects of natural gas market in Ukraine, taking into account existing specificity. This somehow optimizes cost of suppliers in the creation and storage of safety stock and the state which responsible for the risks in the public service sector.

Another, equally important derivative aspect of public policy of creation and storage of natural gas is the turnover of reserves during the year, assuming 
that the turnover of property is one of the three most important factors affecting the profitability of capital (according to Dupont model, the other two are return on sales and financial leverage). Simple calculations 'roughly' demonstrate impressive results on the turnover of stocks:

$$
\mathrm{O}=\frac{\mathrm{P}_{\mathrm{C},}}{\mathrm{C}_{3}}
$$

where $\mathrm{P}_{\mathrm{C}}$ - annual consumption, $\mathrm{C}_{3}$ - average stock.

With annual consumption of 30 billion cubic meters of gas and average gas reserves of 10 billion in UGS the gross turnover of stocks will be only three times a year. If the minimum technological reserve in the PSC is considered about 5 billion cubic meters [4.7 billion cubic meters according to [13], which cannot "turn over", the net turnover of gas reserves will amount 6 times a year, thus the average turnover duration is 2 months. Obviously, for such goods of rapid rotation the turnover duration is too long. Given the existing system of payments for the consumed gas its turnover would have to increase by 1.5-2 times, making 9-12 times a year. following:

To achieve this there should be done the

a) to reduce the power used by UGS by at least one-third, bringing to 20 billion cubic meters from the current 31 billion cubic meters, which will help to reduce the technology stock to 3.2 billion cubic meters;

b) to reduce the average level of gas reserves in underground storage facilities by $1.5-2$ billion cubic meters by optimizing the supply of gas at the beginning of the heating season.

These measures will lead to an increase in gross turnover to 4 times a year, and taking into account the technological stock the turnover of the net may reach 8 times a year. Obviously, we must take into account the pricing environment during the heating season and summer season, because there is always an alternative: to buy during a season of low prices and keep in reserve for the funds or to buy in the mode of actual needs eliminating the storage phase (pumping, screening) of gas in underground gas storage facilities, as for example in a situation similar to the current (early March 2017), when the selection of 20 million cubic meters could be replaced by supplies from Slovak Republic, Poland and Hungary.

Obviously, we must take into account the risks and the outflow of gas from the core zone of underground gas storage facilities into the peripheral stagnant gas deposits zones [15], which increases the amount of passive gas, risks of rejection of project performance of UGS from operational, risks of violations of their cyclical exploitation, etc.

Another important aspect of the natural gas market in Ukraine is pricing, including the costs relating to storage (pumping, screening) of gas [7, 10]. First, the establishment of normative profitability for planned spending does not stimulate to minimize the cost of the gas reserves maintenance. Second, the attribution and distribution of various cost elements of the phases of retention of gas in underground gas storage (pumping, storage, selection) is easy to account for, control and calculation $(100 \%, 50 \%, 25 \%)$, but does not have a sufficient objective reason that discourages optimizing the cost structure. Thirdly, the existence of additional barriers for external gas suppliers to enter (input tariff for gas transit system [7]), compared to the internal. Fourth, the one that needs urgent attention is the issue of costs associated with the creation and maintenance of the technological stock in UGS, which is estimated as 4.8 billion cubic meters, and filled in GTS. Should not the gas market participants bear joint responsibility for the associated with this 'dead' stock (dead, because you can not sell it) costs? All the described factors do not facilitate healthy competition in the natural gas market in Ukraine both among suppliers and/or distributors, and among the parts of gas supply chain.

\section{Conclusions}

1. It should be accepted with no restrictions that the natural gas market in Ukraine is a complicated macro-logistics system, which, in addition to its important strategic function of forming national security, has considerable economic potential, able to significantly influence the GDP, both directly and in terms of synergies. It is important to understand public policy to improve its efficiency and competitiveness.

2. A key set of research and policy for the natural gas market in Ukraine is a requirement for the establishment and maintenance of natural gas reserves: how much, who and when. Implementing typical logistic approaches for choosing external suppliers, coordination of their purchase volume and timing of purchasing and stockpiling can significantly reduce the likelihood of corruption component in the process of gas reverse. Optimization of these requirements can significantly affect the profitability growth of the natural gas market in Ukraine (not only 


\section{Y. V. Krykavskyy, O. S. Kostyuk}

by consumers) and increase its attractiveness to foreign investors.

3. Improvement of the natural gas market in Ukraine requires the introduction of competitive market principles into a pricing system for services provided by the subjects of this market, above all, the GTS, underground gas storage facilities, distribution network. This will lead to a gradual transition to the accepted and fair prices for goods and services.

4. Even for such a very complex macrologistics system as natural gas market the dilemma "security contra economy" does not lose its relevance.

\section{References}

1. Ukrayna voshla $v$ fevral $s$ zapasamy $v$ PKhH 9,885 mlrd kub. m haza / Novyny na UKR.NET// http://www. ukr.net/\#homeDetails/jekonomika/52414741/

2. Ziskochyty z rosiiskoi hazovoi holky: yak zminiuvalos spozhyvannia blakytnoho palyva $v$ Ukraini - Telekanal novyn24//http://24tv.ua/ziskochiti_z_rosiyskoyi_ gazovoyi_golki_yak_zminyuvalos_spozhivannya_blak itnogo_paliva_v_ukrayini_n767507.

3. Uvelychennoe yz-za morozov potreblenye haza rezko sokrashchaet zapasbl v ukraynskykh khranylyshchakh/l https://strana.ua/news/49128-uvelichennoe-iz-zamorozov-potreblenie-gazarezko sokrashaet-zapasy-vukrainskih-hranilishah.html.

4. Novosty эkonomyky - V “Naftohaze" proschytaly kryzysnble stsenaryy sokrashchenyia hazovoho ymporta $v$ otopytelnbi sezon - Stranytsa novosty m.zn.ua//http://m.zn.ua/ECONOMICS/v-naftogazeproschitali-krizisnye-scenarii-sokrascheniyagazovogoimporta-v-otopitelnyy-sezon-235894_.html

5. Pro zatverdzhennia Polozhennia pro Natsionalnu komisiiu, shcho zdi... | vid 10.09.2014 \#715/2014// http://zakon3.rada.gov.ua/laws/show/715/2014

6. Zvidky Ukraina importuie haz: tsikava infohrafika Telekanal novyn 24// http://24tv.ua/zvidki_ukrayina_ importuye_gaz_tsikava_infografika_n771729.

7. Stvorennia rynku hazu: imitatsiia chy realnist? http://m.dt.ua/energy_market/stvorennya-rinku-gazuimitaciya-chi-realnist-_.html.

8. Pro rynok pryrodnoho hazu | vid 09.04.2015 \# 329VIII http://zakonO.rada.gov.uallaws/show/329-19/page.
9. Rada ukhvalyla zakon pro stvorennia stratehichnoho zapasu hazu https://bdzhola.com/news/rada-uhvalilazakon-pro-stvorennja-strategichnogo-zapasu-gazu

10. Novyny - Opryliudniuietsia proekt postanovy, shcho maie oznaky rehuliatornoho akta, - zminy do Kodeksu hazoskhovyshch, Typovoho dohovoru zberihannia (zakachuvannia, vidboru) pryrodnoho hazu i Metodyky vyznachennia ta rozrakhunku taryfiv na posluhy zberihannia (zakachuvannia, vidboru) pryrodnoho hazu shchodo hazoskhovyshch, do yakykh zastosovuietsia rezhym rehulovanoho dostupu http://www.nerc.gov.ua/?news=5747.\%20.

11. Kabmin zmenshyv strakhovyi zapas hazu | Ekonomichna pravda https://www.epravda.com.ua/news/ 2016/11/16/611351/.

12. Krykavskyi Ye.V. Lohistyka dlia ekonomistiv / Krykavskyi Ye.V.// pidruchnyk - 2-e vydannia - Lviv: Vydavnytstvo Lvivskoi politekhniky, 2014. - 476 s. (Seriia "Svit marketynhu i lohistyky", vyp.9).

13. Naftohaz: Zakinchyly zymu iz zapasamy hazu, vyshchymy za prohnozy - 02.03.2017 21:09 - Novyny Ukrinform https://www.ukrinform.ua/rubric-economics/ 2186299-naftogaz-zakincili-zimu-iz-zapasami-gazuvisimi-za-prognozi.html

14. Zapasy hazu v skhovyshchakh Ukrainy znyzylysia do 10 miliardiv kubiv - "Ukrtranshaz" http://www. slovoidilo.ua/2017/01/30/novyna/ekonomika/zapasyhazu-v-sxovyshhax-ukrayiny-znyzylysya-do-10milyardiv-kubiv-ukrtranshaz

15. Otsiniuvannia zapasiv hazu $v$ pidzemnykh skhovyshchakh / O. T. Chernova // Rozrobka rodovyshch: Zb. nauk. pr. - 2015. - T. 9. - S. 267274. - Bibliohr.: 7 nazv. - ukr.

16. Spozhyvannia hazu v Ukraini skorotylosia na 16\%, chastka importu vpala nyzhche 50\% - Ekonomika ZAXID.NET

http://zaxid.net/news/showNews.do?spozhivannya_ga $z u \_v \_u k r a y i n i \_s k o r o t i l o s y a \_n a \_16 \_c h a s t k a \_i m p o r t u$ _vpala_nizhche_50\&objectId=1336974

17. Zymova kampaniia proty "Naftohazu”: khto vynuvatyi $i$ shcho robyty - Detektor media. http://detector.media/infospace/article/123848/201703-07-zimova-kampaniya-proti-naftogazu-khtovinuvatii-i-shcho-robiti/ 